\section{Pacific Northwest}

National Laboratory

Operated by Battelle for the

U.S. Department of Energy

\title{
West Valley High-Level Waste Tank Lay-up Strategies
}

\author{
M. Elmore \\ C. Henderson*
}

April 16, 2001

*Jacobs Engineering Group, Inc.

Prepared for the U.S. Department of Energy under Contract DE-AC06-76RL01830 


\title{
DISCLAIMER
}

This report was prepared as an account of work sponsored by an agency of the United States Government. Neither the United States Government nor any agency thereof, nor Battelle Memorial Institute, nor any of their employees, makes any warranty, express or implied, or assumes any legal liability or responsibility for the accuracy, completeness, or usefulness of any information, apparatus, product, or process disclosed, or represents that its use would not infringe privately owned rights. Reference herein to any specific commercial product, process, or service by trade name, trademark, manufacturer, or otherwise does not necessarily constitute or imply its endorsement, recommendation, or favoring by the United States Government or any agency thereof, or Battelle Memorial Institute. The views and opinions of authors expressed herein do not necessarily state or reflect those of the United States Government or any agency thereof.

\author{
PACIFIC NORTHWEST NATIONAL LABORATORY \\ operated by \\ BATTELLE \\ for the \\ UNITED STATES DEPARTMENT OF ENERGY \\ under Contract DE-AC06-76RL01830
}

Printed in the United States of America

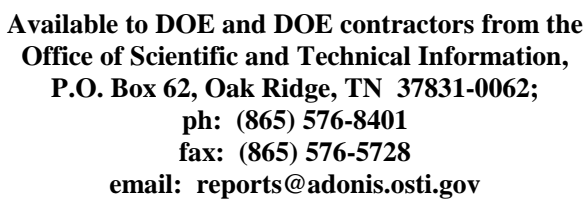

Available to the public from the National Technical Information Service, U.S. Department of Commerce, 5285 Port Royal Rd., Springfield, VA 22161 ph: (800) 553-6847 fax: $(703) 605-6900$

email: orders@ntis.fedworld.gov

online ordering: http://www.ntis.gov/ordering.htm 
PNNL-13902

\section{West Valley High-Level Waste Tank Lay-up Strategies}

April 16, 2001

Prepared for

Tanks Focus Area and

the U.S. Department of Energy

under Contract DE-AC06-76RL01830

Jacobs Engineering Group, Inc., and

Pacific Northwest National Laboratory

Richland, Washington 99352 


\section{CONTENTS}

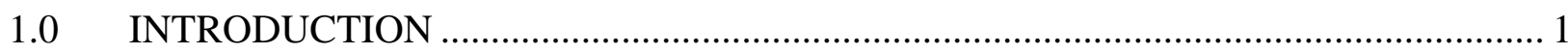

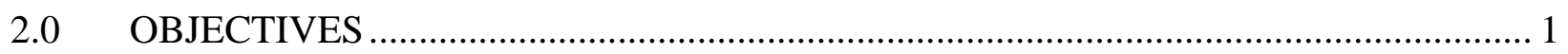

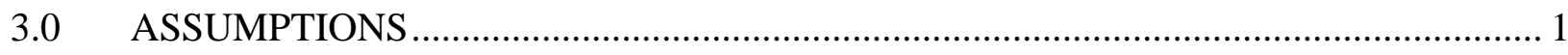

4.0 FUNCTIONS AND REQUIREMENTS FOR TANK LAY-UP ..................................... 1

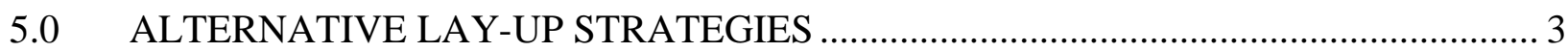

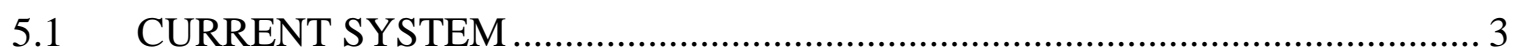

5.2 OTHER POTENTIAL OPTIONS …………............................................... 3

5.2.1 Cathodic Protection for External Tank Surfaces ........................................ 4

5.2.2 Vault Drying System................................................................................ 4

5.2.3 Drying Systems in Both the Vaults and Tanks ........................................... 4

5.2.4 Seal Annulus and Maintain Nitrogen Blanket ............................................... 4

5.2.5 Oxygen Removal Capability................................................................... 4

5.2.6 Argon or Other High Density Inert Gas Instead of Nitrogen....................... 5

5.2.7 Groundwater Interceptor Trench........................................................... 5

5.2.8 Infiltration Barrier Above the Vaults ..................................................... 5

5.2.9 Enhanced Pumping of Groundwater ............................................................ 7

5.2.10 Barrier Around the Vaults......................................................................... 7

5.2.11 Corrosion Inhibitors in the Water Outside the Tanks …………………...... 8

5.2.12 Radionuclide/Hazardous Material Sorbents to the Annulus ....................... 9

5.2.13 Low Strength Grout in Tanks to Stabilize Residual Heels .......................... 9

5.2.14 Fixative to Prevent Suspension of Internal Contamination ......................... 9

5.2.15 Corrosion Monitors in Key Locations ....................................................... 9

5.2.16 Radiation/Contamination Monitors for Early Detection of Any Leakage 10

5.2.17 Complete Removal of All Residual Waste ................................................ 10

5.3 OPTIONS IDENTIFIED AND DISCARDED AS NOT VIABLE ....................... 10

5.3.1 Fill Annulus with Material Impervious to Water........................................ 10

5.3.2 Add a Coating to the Tank and/or Vault Wall ........................................ 10

5.3.3 Assess Worst-Case Impact of Credible Leak............................................ 10

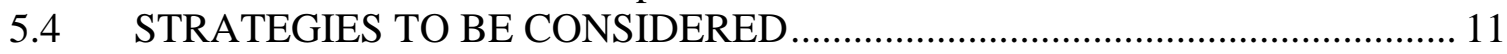

5.4.1 Current System (see Section 5.1) ............................................................. 11

5.4.2 Cathodic Protection (see Section 5.2.1) ..................................................... 11

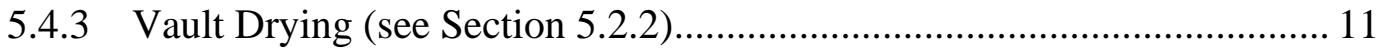

5.4.4 Vault \& Tank Drying (see Section 5.2.3) ................................................. 11

5.4.5 Nitrogen Blanket (see Section 5.2.4) ...................................................... 11

5.4.6 Nitrogen Blanket with Oxygen Removal (see Section 5.2.5) .................... 11

5.4.7 Argon Blanket (see Section 5.2.6) ......................................................... 11

5.4.8 Argon Blanket with Cathodic Protection .................................................... 11

5.4.9 Interceptor Trench (see Section 5.2.7)/Drying ......................................... 11

5.4.10 Trench/Infiltration Barrier (see Section 5.2.8)/Drying .............................. 13

5.4.11 Infiltration Barrier/Drying/Enhanced Pumping (see Section 5.2.9) ......... 13

5.4.12 Groundwater Barrier (5.2.10)/Drying ..................................................... 13 
5.4.13 Infiltration Barrier/Drying .......................................................... 13

5.4.14 Corrosion Inhibitors in Containment Pan (see Section 5.2.11) ................ 13

5.4.15 Sorbents in Annulus (see Section 5.2.12) ............................................ 13

5.4.16 Sorbents with Cathodic Protection.................................................... 13

5.4.17 Low Strength Grout (see Section 5.2.13)......................................... 13

5.4.18 Low Strength Grout/Drying ............................................................ 13

5.4.19 Contamination Fixative (see Section 5.2.14) ...................................... 14

5.4.20 Monitors (see Sections 5.2.15 and 5.2.16) .......................................... 14

5.4.21 Waste Removal (see Section 5.2.17) ................................................ 14

6.0 INFORMATION NEEDS TO SUPPORT LAY-UP DECISION ................................ 14

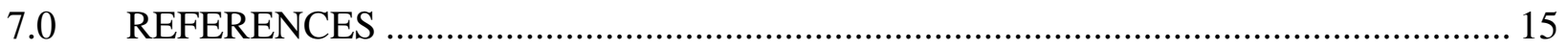

\section{FIGURES}

1. Aerial Photograph of the West Valley Demonstration Project Facilities ........................ 6

2. Cross-Section of Tank and Superstructure ............................................................. 6

3. Diagram of a Viscous Liquid Barrier................................................................. 8

\section{TABLES}

1. Alternative Strategies for West Valley Demonstration Project Tank Lay-Up ................ 12 


\section{LIST OF TERMS}

GCL geosynthetic clay liner

HLW high-level waste

PSX polysiloxane

WVDP West Valley Demonstration Project 


\section{WEST VALLEY HIGH-LEVEL WASTE TANK LAY-UP STRATEGIES}

\subsection{INTRODUCTION}

This report documents completion of Milestone A.2-1, "Issue Tank Lay-Up Strategies for WVDP," in Technical Task Plan RL30WT21A, "Post-Retrieval and Pre-Closure HLW Tank Lay-Up." This task is a collaborative effort among Pacific Northwest National Laboratory, Jacobs Engineering Group Inc., and West Valley Nuclear Services. The primary objective of the overall task is to develop and evaluate conceptual strategies for preclosure lay-up of the two large high-level waste (HLW) storage tanks at the West Valley Demonstration Project (WVDP).

Functions and requirements for tank lay-up were developed and previously documented in "Functions and Requirements for WVDP Lay-Up" (Henderson 2001 [Letter Report \#1]). These functions and requirements will serve as decision criteria to support selection of a strategy for safe and cost-effective lay-up of the HLW tanks.

\subsection{OBJECTIVES}

This report has two objectives:

- Summarize the lay-up strategies already identified and summarize any new strategies

- Describe information or development needs to support prioritization of the lay-up strategies against the decision criteria.

\subsection{ASSUMPTIONS}

The following assumptions apply to the assessment of alternatives for WVDP tank lay-up.

- Current environmental permits will continue.

- HLW will be removed and the tanks will be decontaminated to meet the limits in 10 CFR 61 (Williams 2001).

- The residual waste will be characterized.

- Gaseous and liquid effluent treatment systems will be maintained.

\subsection{FUNCTIONS AND REQUIREMENTS FOR TANK LAY-UP}

The primary function of the tanks and auxiliary systems is to contain the waste and prevent releases to the environment. The primary objective for temporary tank lay-up is to put the tanks and vaults into a safe and stable configuration with minimum capital and operating costs for up to a 20 -year period of time. The requirements listed below will serve as the evaluation criteria for identifying the preferred strategy. Development of these requirements was previously reported (Letter Report \#1). Some of the requirements identified below are firm requirements (e.g., safety) while others are more value based. Weighting factors will be developed as part of 
the decision plan to provide a means for ranking alternative lay-up strategies. The weighting factors can be used as a way to vary the importance or influence of each requirement.

- Comply with regulations and permit requirements - All regulations and permit requirements must be complied with during the lay-up period. Effluent releases must be maintained within permitted limits. This will require maintaining gaseous and liquid treatment capabilities for tank ventilation and potential treatment of liquids pumped from inside or around the vaults.

- Prevent release of tank contents to the groundwater - There shall be no release of any amount of the tank contents to the groundwater. This is a consideration during any preparatory activities and during the lay-up period.

- Ensure acceptable risk to workers and the public - The risks associated with the installation of any new equipment required for the selected option must be as low as reasonably achievable. However, the selected option should result in a reduced risk to workers and the public during the lay-up period.

- Maintain integrity of the tanks - The ability of the tanks to continue to contain the waste residual must be maintained. Further corrosion of the tanks must be controlled, and the structural integrity of the tanks must be ensured.

- Establish a safe operating envelope during temporary lay-up - The operational requirements during the lay-up period must continue to be within safe limits, but reduced monitoring and surveillance should be considered in evaluating options.

- Control construction and operating costs - The cost of installing new equipment and the continued operating costs are considerations for selecting a preferred option. Construction and operating costs must be within projected budgets.

- Utilize accepted methods and technologies - The preferred option should be based on proven construction methods and demonstrated technologies.

- Avoid production of secondary wastes during construction and operation - Options that may produce secondary wastes, especially radioactive wastes that will require further treatment and disposal, should be avoided.

- Preserve future options for decontamination and final closure - The selected lay-up option must maintain the ability to sample the waste, perform additional waste removal, and complete additional decontamination of the tanks if necessary. Also, the lay-up option selected must not preclude either of the currently identified final closure options of in-place stabilization and complete removal.

- Gain acceptance for lay-up - The selected option must be acceptable to stakeholders. Any changes to permits or other requirements must be acceptable to regulatory agencies.

- Reduce monitoring and surveillance - Reductions in monitoring and surveillance, consistent with requirements, is desired. 
Additional requirements or criteria for selecting a preferred strategy for lay-up may be identified when the alternative strategies are ranked.

\subsection{ALTERNATIVE LAY-UP STRATEGIES}

Several alternative actions were identified to provide for continued safe storage of the residual waste in the tanks prior to final closure. The lay-up strategy selected must provide for placing the tanks in a safe, stable, and minimum maintenance mode that does not compromise final closure options. Several alternative approaches are discussed in the following sections. Some of the options identified were deemed not viable for serious consideration. The preferred strategy for lay-up will likely be some combination of options.

\subsection{CURRENT SYSTEM}

The historical methods of corrosion control have been to periodically remove water from the containment pan, control the $\mathrm{pH}$ and nitrite/nitrate ratio of the liquid inside the tanks, and maintain a nitrogen purge inside the vaults. The corrosion-monitoring program has confirmed that the rate of internal pitting corrosion has been maintained with a program of $\mathrm{pH}$ control and nitrite/nitrate ratio control (Chang 1999). The corrosion rate of the tank internals has been controlled in the range of 0.013 to $0.025 \mathrm{~mm} / \mathrm{yr}\left(0.5\right.$ to $\left.1.0 \mathrm{mpy}^{1}\right)($ Chang 1999$)$.

Pumps are currently used to remove water from outside and inside the tank vaults. However, there will continue to be a concern that corrosion to the external surfaces of the tanks could eventually result in penetrations. Corrosion of the external tank walls is primarily from the wet conditions inside the vaults. General corrosion rates determined from corrosion coupons are generally less than $3 \mathrm{mpy}$ and the highest measured rate is $0.188 \mathrm{~mm} / \mathrm{yr}$ (7.4 mpy) (Chang 1999). The external pitting corrosion rate has been estimated at up to $0.3 \pm 0.075 \mathrm{~mm} / \mathrm{yr}$ (12 $\pm 3 \mathrm{mpy})$ (Chang 1998). If this rate has been experienced since the tanks were built, there may be little remaining corrosion allowance at locations prone to pitting.

The nitrogen inerting system has been in operation since August 1996. The oxygen concentration has been maintained at about $13.5 \%$ to $15.5 \%$; oxygen concentration in air is $21 \%$. Using this system has resulted in an estimated decrease in the external corrosion rate of tank 8D-1 by about 33\% (Chang 1999). The nitrogen inerting system also reduces the concentration of other impurities in the gas surrounding the tanks, such as sulfur dioxide, that can also accelerate corrosion.

\subsection{OTHER POTENTIAL OPTIONS}

There are several options that can be considered to ensure safe and cost-effective storage of residual waste remaining in the tanks during the lay-up period. These enhancements include all the options previously identified by West Valley Nuclear Services. These options are individual components that can be selected and combined to create an integrated lay-up strategy as described in Section 5.4. They are described in the following sections.

\footnotetext{
${ }^{1}$ Note: $\mathrm{mpy}=$ mils per year; a mil is $1 / 1000$ of an inch.
} 


\subsubsection{Cathodic Protection for External Tank Surfaces}

Addition of cathodic protection to the tanks has been assessed. One alternative method for cathodic protection identified is to use the containment pan as the sacrificial anode.

The tank $8 \mathrm{D}-2$ containment pan is known to have a hole in it, so use as a sacrificial anode would be reasonable since its original purpose is already compromised. There are several technical and engineering issues that must be resolved before this option could be selected. These include (1) galvanic corrosion on the bottom of the tank, (2) runaway voltage with the impressed current system, (3) protection of welds, (4) assurance that no electrical shorts are present, e.g., pan pump, dip tubes, etc (Chang 1999).

\subsubsection{Vault Drying System}

General textbook corrosion rates of carbon steel in water are generally 0.075 to $0.20 \mathrm{~mm} / \mathrm{yr}$ ( 3 to $8 \mathrm{mpy}$ ) and pitting corrosion rates are generally 2.5 to 3.5 times the general corrosion rate. External tank corrosion could be virtually eliminated if the tank surfaces were kept dry. The criterion would be to maintain the relative humidity below $30 \%$ in the air surrounding the tanks (Chang 1998). The drying system would include a dehumidifier and heater for air forced into the vaults. The exhaust air leaving the vaults would pass through high-efficiency particulate air filters.

\subsubsection{Drying Systems in Both the Vaults and Tanks}

An additional enhancement to also reduce corrosion inside the tanks is to install drying systems both inside the vaults and inside the tanks. Drying the inside of the tanks could result in contamination of the exhaust air by particles of dried solids in the tanks being suspended by the airflow through the tanks. However, once all the liquid inside the tanks was evaporated, only a very low flow of heated, dehumidified air would be required to maintain low humidity inside the tanks. Keeping the tank internals the same temperature, as the external surfaces would also prevent condensation of water on the tanks' external walls.

\subsubsection{Seal Annulus and Maintain Nitrogen Blanket}

The current nitrogen inerting system has not been effective in maintaining the desired concentration of oxygen in the vault below $0.9 \%$ as specified in the design criteria (WVNS-DC-065). Sealing the vault as well as possible and then adding additional amounts of cold nitrogen to displace air from the vault should result in a more effective blanket and lower oxygen concentrations.

\subsubsection{Oxygen Removal Capability}

This option could be used in combination with either of the two preceding options. Recirculated blanket gas could be passed through a device to remove oxygen. Such a system would be efficient only if air in-leakage is significantly reduced. 


\subsubsection{Argon or Other High Density Inert Gas Instead of Nitrogen}

Using Argon instead of Nitrogen as the blanket gas would be more effective in displacing air because Argon is heavier than air. This option has been considered in the past, as early as 1997 (Meess 1997).

\subsubsection{Groundwater Interceptor Trench}

One of the primary methods of preventing or significantly reducing corrosion on the outside of the tanks is to maintain very low humidity in the vaults. In order to do this, the ingress of water into the vaults must be prevented. The principal source of water into the vaults appears to be from percolation of rainwater and snowmelt through the soil layer above the vaults and groundwater flow in the soil/sand layer above the compacted clay layer. One method to significantly reduce this infiltration is to divert runoff and groundwater flow. This could be accomplished by installing an interceptor trench down to the compacted clay layer upgradient of the tanks. This trench would be filled with coarse gravel and perforated pipe would be installed at the bottom of the trench to collect and remove excess water. The trench would be connected to a culvert to carry water to an appropriate location downgradient from the tanks and vaults. This would be a totally passive system. Pumping of water from the vaults and the well between the vaults could be eliminated or significantly reduced.

\subsubsection{Infiltration Barrier Above the Vaults}

A principal source of water ingress into the tank vaults appears to be from infiltration from above the vaults. A cover to divert rainwater away from the area would be effective in preventing this water from entering the vaults. This barrier could be a clay cap, a membrane, a roof or some other cover. Installation of a barrier above the vaults is complicated by the superstructure that was installed to support the mobilization pumps and penetrations into the soil above the tanks and vaults. Figure 1 is an aerial photograph showing the super-structure. Figure 2 is a cross-section showing penetrations through the soil (EML-609).

Grout was added around the penetrations into the tank 8D-2 vault and this significantly reduced water intrusion (from about 1,900 L/day [500 gal/day] to about $45 \mathrm{~L} /$ day [12 gal/day]). However, this increased the water intrusion into the tank 8D-1 vault from 190 to 1,900 L/day (50 to 500 gal/day). Grout was then added around the tank 8D-1 vault accessway with similar results.

One alternative cover layer is a capillary layer barrier, which consists of a fine-over-coarse soil arrangement. The capacity of capillary barriers to laterally divert downward moving water is the key to their success. Another alternative is a dry barrier, in which atmospheric air is circulated through a coarse layer within the cover to remove water vapor. Yet another approach is a geosynthetic clay liner (GCL) cover. This is a barrier manufactured with a thin layer of bentonite clay supported by geotextiles and/or geomembranes. A $5 \mathrm{~mm}(0.2 \mathrm{in}$.) thick GCL has the same hydraulic conductivity as a $1 \mathrm{~m}$ (40 in.) thick compacted soil layer.

A geomembrane can also be used on top of compacted soil or a GCL. Geomembranes are available in a variety of materials, such as polyvinyl chloride, very-low-density polyethylene, and linear-low-density polyethylene. 
Figure 1. Aerial Photograph of the West Valley Demonstration Project Facilities

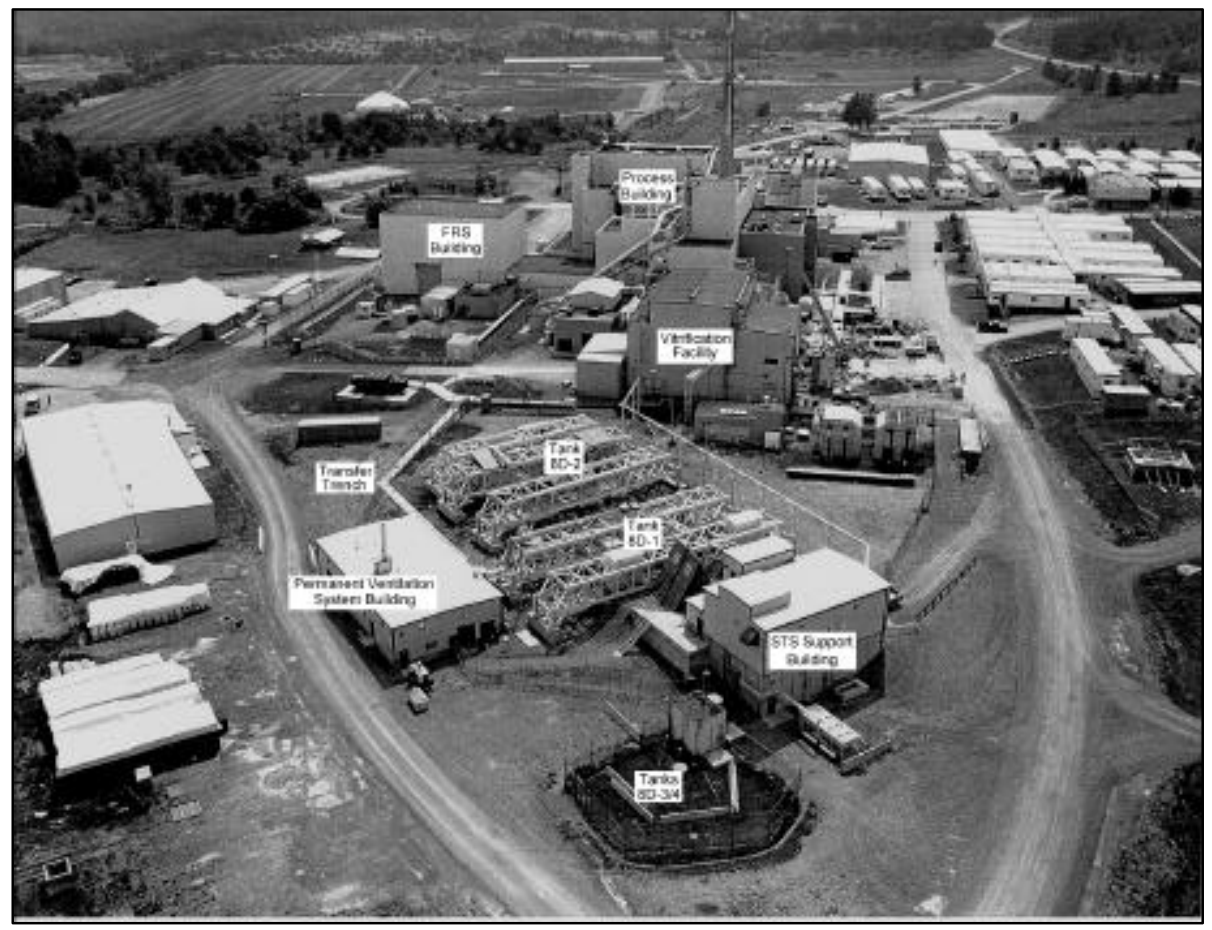

Figure 2. Cross-Section of Tank and Superstructure

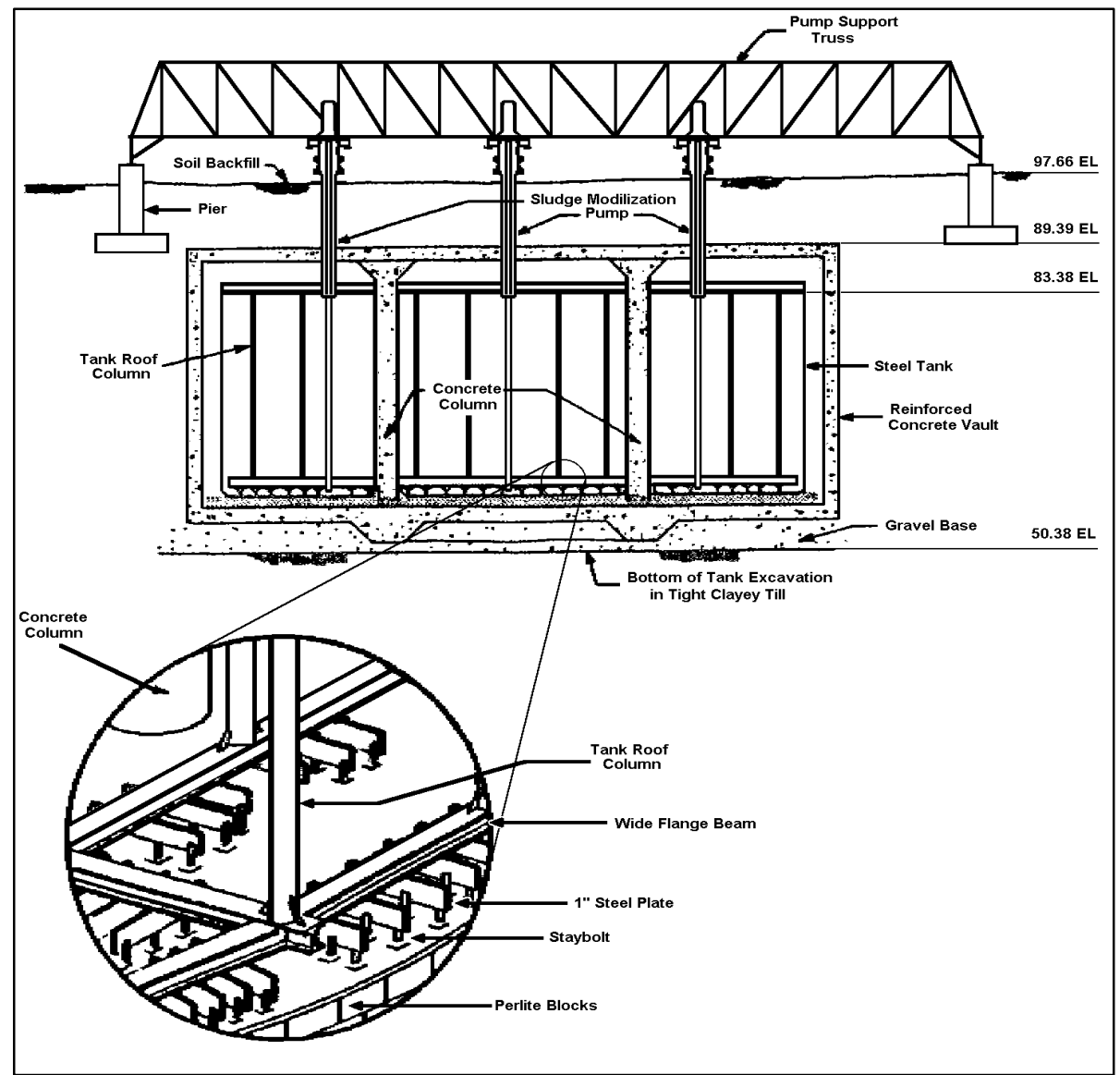


Another choice of a barrier is to construct a roof over the vaults. This roof could also serve as a cover during final closure of the tanks. Gutters and drains would also be needed on the adjacent buildings to divert that water downgrade from the tank farm area.

Addition of a cover barrier would be simplified with prior removal of the superstructure. This would first require removal of the mobilization pumps or abandoning the pumps in place. A roof could possibly be built on or above the superstructure.

\subsubsection{Enhanced Pumping of Groundwater}

To ensure that water will not infiltrate into the vaults from groundwater around and below the vaults, the capability to pump water from the gravel bed below the vaults could be maintained or enhanced. Water is currently pumped from a well between the vaults, but the water table is not pumped to below the bottom of the vaults. The hydrology is not known well enough to determine the volume of water that would need to be pumped to maintain the water table below the level of the vaults. More frequent operation of the current system or additional wells and pumps may be needed. Elimination of surface water infiltration and possibly also a reduction in groundwater flow (as described in the preceding sections) may be necessary for this option to be effective.

\subsubsection{Barrier Around the Vaults}

A solid barrier to groundwater flow could be installed if more positive exclusion of groundwater from the vaults is needed. This barrier could be a solid grout wall, a frozen soil barrier, or a viscous liquid barrier.

Jet Grout Barriers have been demonstrated at the Hanford 400 Area and at Brookhaven National Laboratory. At Hanford, a cone-shaped barrier was placed around a simulated waste form. The barrier material was cement and a high-molecular polymer. The barrier integrity was verified using nonintrusive geophysical techniques. At Brookhaven, a v-shaped cementitious barrier was emplaced beneath a mixed waste pit approximately $6 \mathrm{~m}(20 \mathrm{ft})$ wide by $12 \mathrm{~m}(40 \mathrm{ft})$ long and $6 \mathrm{~m}$ (20 ft) deep (SCFA 1994).

Another type of barrier is a frozen soil barrier. Frozen soil barrier technology consists of installing subsurface heat transfer devices around a contaminant source to freeze soil pore water, which creates a frozen soil boundary that is impervious to groundwater movement. The frozen soil barrier isolates the contaminant source from the surrounding groundwater, preventing transport of contaminants to adjacent areas. The barrier is maintained in situ until the source of contamination is physically removed, treated, decayed to acceptable levels, or otherwise remediated. At that point, the system is powered down and the frozen barrier eventually thaws. If the barrier is removed prior to remediation, the site will return to its pre-barrier configuration, as will the mechanism of contaminant transport from the source.

Demonstration of an innovative frozen soil barrier technology for containment of subsurface radioactive contaminants was conducted at Oak Ridge National Laboratory in Oak Ridge, Tennessee, from September 1996 through September 1998. Groundwater monitoring and dye tracer results indicate that the frozen soil barrier hydraulically isolates a hazardous waste area from the surrounding area. The project cost approximately $\$ 1,809,000$, including design, 
installation, startup, system operation, engineering oversight, site infrastructure upgrades, and pre- and post-barrier verification studies. The system requires approximately 288 kilowatt-hours of electrical power per day to maintain the frozen soil barrier (USEPA 1999).

Another barrier system uses inert liquids that increase their viscosity after being injected into the soil to form an impermeable wall. These barriers are similar to frozen soil barriers in that they surround and contain a plume. Unlike frozen soil barriers, viscous liquid barriers are a gel-like mass rather than a wall of frozen subsurface moisture.

The U.S. Department of Energy has investigated three types of viscous liquid barrier materials (SCFA 1997). The first type of fluid is a member of the polybutene, or PB, family.

The viscosity of $\mathrm{PB}$ is temperature sensitive. It is practically solid at surrounding groundwater temperatures. PB will not dissolve in water and is impermeable to water and gases. Installation of PB barriers requires heating the soil. The liquid is injected at the same temperature as the soil, then the barrier forms as the soil cools. The second fluid is polysiloxane (PSX). PSX is a silicon-based polymer that is unaffected by the chemistry of the aquifer. The viscosity increase in PSX is the result of mixing with other substances and temperature control. The third barrier fluid is colloidal silica. Colloidal silica is a silicon-based grout that is installed using a cooling process, or gelation. The $\mathrm{pH}$, temperature, and the chemistry of the soil and groundwater affect the time required for colloidal silica to gel.

A viscous liquid barrier could be placed completely around the tanks and vaults to totally entomb them. This would prevent any water intrusion during the temporary lay-up period. Figure 3 is a graphic showing a viscous liquid barrier (SCFA 1997).

\section{Figure 3. Diagram of a Viscous Liquid Barrier}

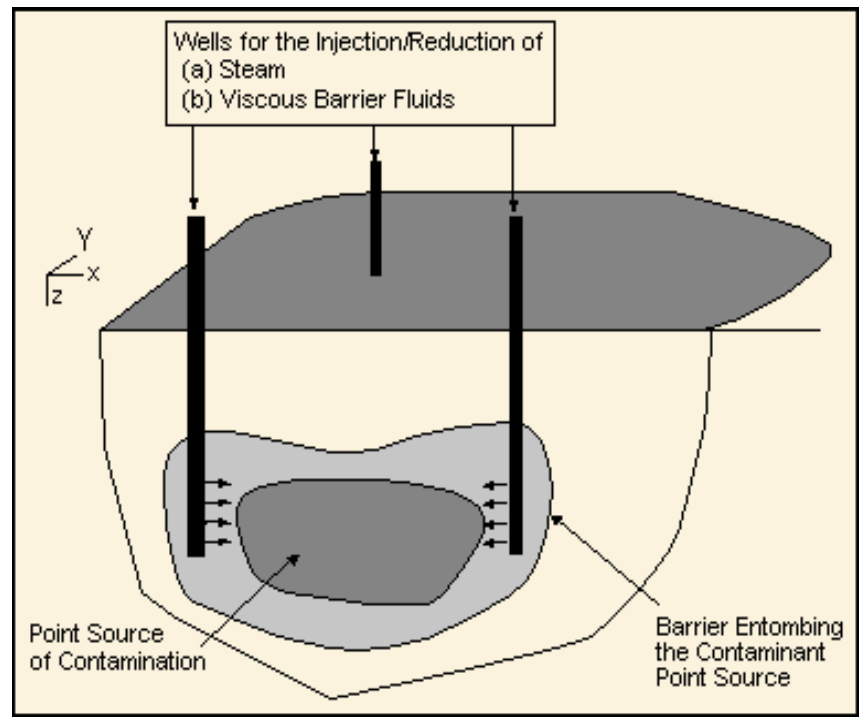

\subsubsection{Corrosion Inhibitors in the Water Outside the Tanks}

Adding corrosion inhibitors to water in the containment pans may reduce the corrosion on the outer walls. Corrosion inhibitors would not be effective for reducing corrosion in the high humidity vapor space above the liquid level. 


\subsubsection{Radionuclide/Hazardous Material Sorbents to the Annulus}

An ion exchange and/or sorbent material could be added to the secondary containment pan and/or the vault to capture the radioactive species before they could migrate outside the vault. Additional information would be required to determine if a combination of materials could be selected which would be effective for all the species of concern.

\subsubsection{Low Strength Grout in Tanks to Stabilize Residual Heels}

This option provides a method for temporarily fixing the residual waste in the tank. Nearly all the residual liquid would have to be removed before the grout was added. A low strength grout would be necessary so that it could be removed in the future if final closure requires additional decontamination of the tanks or complete removal of the tanks.

\subsubsection{Fixative to Prevent Suspension of Internal Contamination}

Another option for temporary stabilization of the residual material in the tank would be to spray a coating to prevent any suspension of contamination. This option could be used in combination with the option to keep the inside of the tanks dry to prevent corrosion or to reduce contaminated solids suspension if the tank contents are allowed to dry during the lay-up period. In fact, the tank contents would first have to be dry before a fixative could be applied.

\subsubsection{Corrosion Monitors in Key Locations}

Continuous corrosion monitors could be installed in the tanks and vaults. These monitors would provide an indication of accelerated corrosion due to unexpected changes.

The electrochemical noise probe is being developed as a corrosion-monitoring tool for HLW tanks. This technique can provide real-time, on-line measurements of the corrosion processes in the tank, including the most probable processes of pitting and stress corrosion cracking. Development of the electrochemical noise probe was initiated at Hanford (3 units have been deployed) and is being adapted for the Savannah River Site. Development and deployment of a stainless steel probe for application at the Oak Ridge Reservation is planned. Data from the currently installed probes is being analyzed to validate the electrochemical noise corrosion probe as an alternative for monitoring HLW tank corrosion. An electrochemical noise probe may be an acceptable method for monitoring the corrosion of the WVDP tanks during the lay-up period (PNNL-13339).

A corrosion species monitor is being developed by the U.S. Department of Energy Characterization, Monitoring and Sensor Technology Crosscutting Program as a technique for real-time, on-line monitoring of waste chemistry. A robust, in situ probe that uses Raman spectroscopy for analysis is capable of measuring the nitrite/nitrate concentration and the hydroxide concentration. EIC Laboratories are developing the Raman probe. The corrosion species monitor will be combined with an electrochemical noise corrosion probe (see above) for deployment at the Savannah River Site.

Depending on the composition of waste in the WVDP carbon-steel tanks, the tanks may be susceptible to nitrate ion-induced corrosion cracking. Monitoring and maintaining adequate 
nitrite/nitrate ratio and hydroxide ion levels prevents this degradation. Sensors that could monitor all three species could reduce the costs of current baseline sampling and laboratory analysis methods and could minimize the addition of corrosion inhibitor solution.

\subsubsection{Radiation/Contamination Monitors for Early Detection of Any Leakage}

Radiation and/or contamination monitors in the tanks or vaults would indicate changes in conditions and possible leaks. There are several monitors on the market that could be installed to give early warning of a tank failure. A gamma monitor would need to be shielded from the background radiation inside the tank, or an alpha and/or beta monitor could be used.

\subsubsection{Complete Removal of All Residual Waste}

Very aggressive decontamination could be employed prior to temporary tank lay-up. Removal of all but a very small amount of residual contamination may preclude the need for any further action prior to final closure. This option might have a lower lay-up cost than other options that require continued operation of equipment (such as the nitrogen purge system) and surveillance. However, the criteria for what constitutes adequate decontamination are not established and any residual contamination could present a risk to the environment.

\subsection{OPTIONS IDENTIFIED AND DISCARDED AS NOT VIABLE}

\subsubsection{Fill Annulus with Material Impervious to Water}

A waterproof material, such as that used for a viscous liquid barrier, could be injected into the annulus. To be effective, the vault would probably need to be dried before the material is added. Verification of effective application to the entire tank surface would be difficult, especially the bottom of the tank. Assurance that moisture would not migrate between the material and the tank wall would also be difficult.

\subsubsection{Add a Coating to the Tank and/or Vault Wall}

A coating could be applied to the exterior tank wall to protect the metal surfaces from moisture. This would require cleaning of rust and other corrosion products from the walls and drying the walls before applying the coating. This disruption of the surface could actually cause a leak. Also, application to the bottom of the tank would not be possible.

\subsubsection{Assess Worst-Case Impact of Credible Leak}

An assessment of the impact of a credible loss of material from the tanks could be assessed. The fate and transport of residuals into the environment could be modeled assuming tank failure. This might determine that the risk is acceptable. However, this option is unlikely to achieve regulatory and stakeholder acceptance. 


\subsection{STRATEGIES TO BE CONSIDERED}

There are many combinations of the options described above that would constitute reasonable strategies for tank lay-up. The combinations recommended for consideration are listed below and are depicted on Table 1 on the next page. There may be other options and combinations of options that can be considered when the final ranking is done. The options are categorized as "wet" or "dry." The "dry" options would result in preventing further corrosion of the tanks during the lay-up period. The "wet" options would result in some amount of continued corrosion, but with reasonable assurance of no loss of radioactive material to the environment.

\subsubsection{Current System (see Section 5.1)}

\subsubsection{Cathodic Protection (see Section 5.2.1)}

\subsubsection{Vault Drying (see Section 5.2.2)}

\subsubsection{Vault \& Tank Drying (see Section 5.2.3)}

\subsubsection{Nitrogen Blanket (see Section 5.2.4)}

\subsubsection{Nitrogen Blanket with Oxygen Removal (see Section 5.2.5)}

Oxygen removal from the gas surrounding the tanks to a low level (the original design criterion for the nitrogen purge was less than $0.9 \%$ oxygen) may provide adequate protection without additional measures taken to keep the vaults dry. An efficient nitrogen blanket (recirculating system) would be required for this option.

\subsubsection{Argon Blanket (see Section 5.2.6)}

This is an enhancement of using argon instead of nitrogen to improve the displacement of oxygen and other corrosion-inducing gases from the vaults. Proper use of an argon blanket should not require additional capability for oxygen removal.

\subsubsection{Argon Blanket with Cathodic Protection}

This is an enhancement of using argon instead of nitrogen to improve the displacement of oxygen and other corrosion-inducing gases from the vaults in combination with cathodic protection for additional assurance of corrosion control.

\subsubsection{Interceptor Trench (see Section 5.2.7)/Drying}

Installation of an interceptor trench would enhance the ability to keep the vaults at $<30 \%$ relative humidity. The clay layer surrounding the vaults has a very low permeability to water flow, so a trench to that depth would be very effective in collecting surface water runoff and groundwater in the upper sand/soil layer and diverting it downgrade from the tanks and vaults. 
Table 1. Alternative Strategies for West Valley Demonstration Project Tank Lay-Up

\begin{tabular}{|c|c|c|c|c|c|c|c|c|c|c|c|c|c|c|c|c|c|c|c|c|}
\hline Strategy & $\begin{array}{l}\text { Dry or } \\
\text { Wet } \\
\text { Option }\end{array}$ & $\begin{array}{l}\text { Nitrogen } \\
\text { Inerting }\end{array}$ & $\begin{array}{c}\text { pH } \\
\text { Control }\end{array}$ & $\begin{array}{c}\text { Cathodic } \\
\text { Protection }\end{array}$ & $\begin{array}{c}\text { Vault } \\
\text { Drying }\end{array}$ & $\begin{array}{c}\text { Tank } \\
\text { Drying }\end{array}$ & $\begin{array}{l}\text { Nitrogen } \\
\text { Blanket }\end{array}$ & $\begin{array}{c}\text { Ar } \\
\text { Inerting }\end{array}$ & $\begin{array}{c}\text { Oxygen } \\
\text { Removal }\end{array}$ & \begin{tabular}{|c|} 
Intercep- \\
tor \\
Trench
\end{tabular} & $\begin{array}{l}\text { Ground- } \\
\text { water } \\
\text { Barrier }\end{array}$ & $\begin{array}{c}\text { Infiltra- } \\
\text { tion } \\
\text { Barrier }\end{array}$ & $\begin{array}{l}\text { Enhanced } \\
\text { Pumping }\end{array}$ & \begin{tabular}{|c|} 
Corrosion \\
Inhibitors
\end{tabular} & $\begin{array}{c}\text { Sorbents } \\
\text { in } \\
\text { Annulus }\end{array}$ & \begin{tabular}{|c} 
Low \\
Strength \\
Grout
\end{tabular} & $\begin{array}{c}\text { Contami- } \\
\text { nation } \\
\text { Fixative }\end{array}$ & $\begin{array}{l}\text { Corrosion } \\
\text { Monitors }\end{array}$ & \begin{tabular}{|c|} 
Radiation/ \\
Contami- \\
nation \\
Monitors
\end{tabular} & $\begin{array}{c}\text { Complete } \\
\text { Waste } \\
\text { Removal }\end{array}$ \\
\hline Current System & Wet & $\mathrm{X}$ & $\mathrm{X}$ & & & & & & & & & & & & & & & & & \\
\hline Cathodic Protection & Wet & $\mathrm{x}$ & $\mathrm{x}$ & $\mathrm{x}$ & & & & & & & & & & & & & & & & \\
\hline Vault Drying & Dry & & $\mathrm{x}$ & & $\mathrm{X}$ & & & & & & & & & & & & & & & \\
\hline Vault \& Tank Drying & Dry & & & & $\mathrm{x}$ & $\mathrm{x}$ & & & & & & & & & & & & & & \\
\hline Nitrogen Blanket & Wet & & $\mathrm{X}$ & & & & $\mathrm{x}$ & & & & & & & & & & & & & \\
\hline $\begin{array}{l}\text { Nitrogen Blanket w/Oxygen } \\
\text { Removal }\end{array}$ & Wet & & $\mathrm{x}$ & & & & $\mathrm{x}$ & & $\mathrm{x}$ & & & & & & & & & & & \\
\hline Argon Blanket & Wet & & $\mathrm{x}$ & & & & & $\mathrm{x}$ & & & & & & & & & & & & \\
\hline $\begin{array}{l}\text { Argon Blanket w/Cathodic } \\
\text { Protection }\end{array}$ & Wet & & $\mathrm{x}$ & $\mathrm{x}$ & & & & $\mathrm{x}$ & & & & & & & & & & & & \\
\hline Interceptor Trench/Drying & Dry & & $\mathrm{x}$ & & $\mathrm{x}$ & & & & & $\mathrm{X}$ & & & & & & & & & & \\
\hline Trench/Infiltration Barrier/Drying & Dry & & $\mathrm{x}$ & & $\mathrm{x}$ & & & & & $\mathrm{X}$ & & $\mathrm{x}$ & & & & & & & & \\
\hline \begin{tabular}{|l|} 
Trench/Infiltration \\
Barrier/Drying/Enhanced Pumping
\end{tabular} & Dry & & $\mathrm{x}$ & & $\mathrm{x}$ & & & & & $\mathrm{X}$ & & $\mathrm{x}$ & $\mathrm{x}$ & & & & & & & \\
\hline Groundwater Barrier/Drying & Dry & & $\mathrm{x}$ & & $\mathrm{x}$ & & & & & & $\mathrm{x}$ & & & & & & & & & \\
\hline Infiltration Barrier/Drying & Dry & & $\mathrm{x}$ & & $\mathrm{x}$ & & & & & & & $\mathrm{x}$ & & & & & & & & \\
\hline Corrosion Inhibitors in Vault & Wet & $\mathrm{x}$ & $\mathrm{x}$ & & & & & & & & & & & $\mathrm{X}$ & & & & & & \\
\hline Sorbents in Annulus & Wet & $\mathrm{X}$ & $\mathrm{X}$ & & & & & & & & & & & & $\mathrm{x}$ & & & & & \\
\hline Sorbents with Cathodic Protection & Wet & $\mathrm{x}$ & $\mathrm{x}$ & $\mathrm{X}$ & & & & & & & & & & & $\mathrm{x}$ & & & & & \\
\hline Low Strength Grout & Wet & $\mathrm{x}$ & & & & & & & & & & & & & & $\mathrm{X}$ & & & & \\
\hline Low Strength Grout/Drying & Dry & & & & $\mathrm{x}$ & $\mathrm{x}$ & & & & & & & & & & $\mathrm{x}$ & & & & \\
\hline Contamination Fixative/Drying & Dry & & & & $\mathrm{x}$ & $\mathrm{X}$ & & & & & & & & & & & $\mathrm{X}$ & & & \\
\hline Monitors & Wet & & $\mathrm{x}$ & & & & & & & & & & & & & & & $\mathrm{X}$ & $\mathrm{x}$ & \\
\hline Waste Removal & Wet & & & & & & & & & & & & & & & & & & & $\mathrm{x}$ \\
\hline
\end{tabular}




\subsubsection{Trench/Infiltration Barrier (see Section 5.2.8)/Drying}

To increase the effectiveness of a trench, a domed clay cap, roof or some other cover barrier could be added above the vaults to divert rainwater and snowmelt to the trench rather than infiltrating through the soil to the vaults.

\subsubsection{Infiltration Barrier/Drying/Enhanced Pumping (see Section 5.2.9)}

If the combination of a trench, infiltration barrier and drying system was not effective, then additional pumping of water from inside and below the vaults could be instituted. The need for additional pumping is unlikely.

\subsubsection{Groundwater Barrier (5.2.10)/Drying}

A barrier around the vaults may be a more positive means to preclude water intrusion than would an interceptor trench. However this would be a much more costly approach and may not be necessary. Also, ponding (perched water) could accumulate behind the barrier.

\subsubsection{Infiltration Barrier/Drying}

A barrier above the tanks would be very effective in preventing water intrusion into the vaults. The combination of a barrier above the vaults and a drying system (no interceptor trench or barrier) may be adequate for keeping the vault humidity within an acceptable level. This is dependent on the amount of water that could infiltrate the vaults from groundwater flow alone, which appears to be quite small.

\subsubsection{Corrosion Inhibitors in Containment Pan (see Section 5.2.11)}

\subsubsection{Sorbents in Annulus (see Section 5.2.12)}

\subsubsection{Sorbents with Cathodic Protection}

This would be a relatively low cost option of adding a cathodic protection system and also sorbents for added protection in the unlikely event of a leak. However, reliable corrosion control with cathodic protection alone is uncertain.

\subsubsection{Low Strength Grout (see Section 5.2.13)}

\subsubsection{Low Strength Grout/Drying}

This would be the combination of adding a low strength grout and a drying system for the tanks and vaults. The drying system would be very effective in reducing corrosion and the grout would stabilize the radionuclides and reduce or possibly prevent leakage even if a penetration in the tank wall developed. 


\subsubsection{Contamination Fixative (see Section 5.2.14)}

This would be the combination of a fixative and a drying system for the tanks and vaults. The drying system would be very effective in reducing corrosion and the fixative would stabilize the radionuclides and dispersion into the off-gas system.

\subsubsection{Monitors (see Sections 5.2.15 and 5.2.16)}

\subsubsection{Waste Removal (see Section 5.2.17)}

\subsection{INFORMATION NEEDS TO SUPPORT LAY-UP DECISION}

Several options for temporary lay-up of the tanks have been previously proposed and partially assessed. Other options have only recently been proposed. The principal information needs for a final decision on the preferred approach are listed below.

- A better estimate of the remaining corrosion allowance for the tanks.

- An estimate of the maximum rate of surface runoff from rain and/or snowmelt to establish the size of an interceptor trench in order to determine a cost estimate for that option. Are there existing storm sewers or other drainage systems?

- Data to establish if pumping from below the vaults alone would reduce water infiltration into the vaults low enough for a drying system to be effective.

- Determination of whether maintaining a liquid inventory inside the tanks with continued chemistry adjustments is adequate to control internal corrosion.

- Determination of whether effective control of the oxygen concentration in the gas in the annuli alone can control external corrosion within an acceptable rate. If so, is an oxygen removal system needed or will a better inert gas system suffice?

- Determine if a system to maintain the vaults and all external surfaces of the tanks dry is necessary to ensure an acceptable corrosion rate.

- Determine if a tank wall penetration must be prevented during lay-up or if small penetrations that would not result in releases outside the tanks or vaults would be acceptable.

- Resolution of the technical and engineering issues related to cathodic protection (see Section 5.1.2).

- Determination of the acceptability of using argon rather than nitrogen due to the higher cost and safety concerns.

- Determination of whether the pumps in the catch pans need to be relocated to be at the lowest point.

- Determine if sorbent material(s) could capture leaking radionuclides. 
- Estimates of the expected life of potential groundwater barrier systems.

- A more detailed assessment of adding corrosion inhibitors to the water in the vault.

- Feasibility of decontamination prior to lay-up precluding the need for any further preparation for lay-up.

- Updates to existing preliminary cost estimates and new preliminary cost estimates for several options, including:

- Installation of an interceptor trench or an underground barrier

- Installation of an infiltration barrier

- Addition of a roof above the vaults and tanks

- Installation and operation of an oxygen removal system

- Continuous corrosion monitoring of tanks' external surfaces.

\subsection{REFERENCES}

10 CFR 61, "Licensing Requirements for Land Disposal of Radioactive Waste," Code of Federal Regulations, as amended.

Chang, J.Y., D.C. Meess, S.M. Barnes, and F.W. Damerow, 1998, "Corrosion Monitoring and Control for Tanks 8D-1, 8D-2 and the Vitrification Melter, Volume 1," The Fifth Annual Technical Review Meeting at West Valley, New York, September 21-22.

Chang, J.Y., D.C. Meess, and S.M. Barnes, 1999, "Corrosion Monitoring and Control for Tanks 8D-1, 8D-2 and the Vitrification Melter, Volume 2," The Sixth Annual Technical Review Meeting at West Valley, New York, September 21-22.

EML-609, 2000, West Valley Demonstration Project Waste Management Area \#3 - Closure Alternative I, Environmental Measurements Laboratory, New York, New York.

Henderson, C., 2001, "Contract No. TTP RL30WT21A, Milestone No. A.1-1, Submittal of Functions and Requirements for WVDP Tank Lay-up," (Letter Report \#1 to Michael Terry, Safety Technology Integration Manager, Tanks Focus Area, PNNL, March 15), Jacobs Engineering Group Inc., Richland, Washington.

Meess, D.C. and J.Y. Chang, 1997, "Corrosion Monitoring and Control for Tanks 8D-1 \& 8D-2," The Fourth Annual Technical Review Meeting at West Valley, New York, September 8-9.

PNNL-13339, 2000, Multiyear Program Plan, FY01-FY05, Tanks Focus Area, Pacific Northwest National Laboratory, Richland, Washington.

SCFA, 1994, Subsurface Contaminants Focus Area, Fact Sheet on Close-Coupled Jet Grout Barrier, access page located at http://www.envnet.org/scfa/archive/stc/jetgrout.htm, accessed on March 21, 2001. 
SCFA, 1997, Subsurface Contaminants Focus Area, Fact Sheet on Viscous Liquid Barrier, access page located at http://www.envnet.org/scfa/prodlines/stcr/factsheets/visliq.htm, accessed on March 21, 2001.

USEPA, 1999, United States Environmental Protection Agency, Innovative Freeze Barrier Installation at ORNL, access page located at http://www.epa.gov/tio/products/newsltrs/ttrend/tt0299.htm, accessed on March 21, 2001.

Williams, A.C., 2001, "Expectations for High-Level Waste (HLW) Removal from the Waste Tank Farm" (letter to Robert Campbell, President, West Valley Nuclear Services Company, February 7), West Valley Demonstration Project, Ohio Field Office, U.S. Department of Energy, West Valley, New York.

WVNS-DC-065, 1995, Design Criteria - Inert Gas System for HLW Tanks 8D-1 and 8D-2 Vaults, West Valley Nuclear Services, West Valley, New York. 